\title{
BAGAIMANA MENGAJARKAN GERAK LOKOMOTOR PADA ANAK USIA DINI?
}

\author{
Heri Yusuf Muslihin \\ Universitas Pendidikan Indonesia Kampus Tasikmalaya \\ heriyusuf@upi.edu
}

(Received: Mei 2018; Accepted: Mei 2018; Published: Juni 2018)

\begin{abstract}
Normally all people have fundamental movement. In the fact, there are people had not normally fundamental movement. This condition became when children play with his friend, or they played without supervision from their parents. This article explain about how the teacher sent material fundamental movement (walking, running and jumping), and the kind of walking, running and jumping technique. Fundamental movement was sending to children with Teacher, and the kind of material. Beside done
\end{abstract}

Keywords : Lokomotor Motion, Early Childhood, Walking, Running and Jumping

\begin{abstract}
ABSTRAK
Gerak dasar adalah gerak yang pasti dimiliki oleh setiap individu yang normal. Kenyataan di lapangan masih ada individu yang keterampilan gerak dasarnya tidak normal. Kondisi seperti ini diakibatkan oleh karena kebiasaan yang dilakukan oleh anak-anak saat bermain. Perlu kiranya dalam artikel ini dijelaskan tentang bagaimana gerak dasar lokomotor berupa cara berjalan, berlari dan melompat yang benar, serta bagaimana cara memberikan materi pelajaran kepada para peserta didik. Selain cara melakukan gerak dasar dan bentuk latihan yang benar diberikan kepada anak didik, penting juga kiranya diberikan pengetahuan serta pengalaman gerak lainnya, untuk memperkaya pengetahuan dan wawasan tentang gerak yang benar dan gerak yang salah serta variasi gerak dari gerakan dasar tersebut. Gerak dasar harus diberikan oleh guru secara terpola untuk membentu meningkatkan keterampilan gerak para peserta didik sesuai dengan pertumbuhan dan perkembangannya. Oleh karena itu guru harus memiliki pengetahuan dan teknik yang mendasar untuk meningkatkan keterampilan gerak dasar pada peserta didik dengan baik dan benar.
\end{abstract}

\section{Kata Kunci : Gerak Lokomotor, Anak Usia Dini, Berjalan, Berlari dan Melompat}

\section{PENDAHULUAN}

Gerak dasar bagi anak merupakan satu hal yang penting dalam kehidupan anak, sebagai bekal hidup di kemudian hari. Tidak sedikit anak yang gerak dasarnya tidak berkembang secara optimal. Ada juga anak yang perkembangan geraknya sesuai dengan tingkat usianya namun dalam kenyataannya, ada kesalahan dalam melaksanakan gerak tersebut. Oleh karena itu dalam pelaksanaannya, pengajaran Pendidikan Usia Dini (PAUD) seorang pendidik sangat berperan penting untuk dapat memberikan pembelajaran gerak dasar yang baik. Sehingga peserta didik dapat memperoleh manfaat dengan melakukan bentuk gerak dasar yang baik dan benar.

Gerak dasar yang harus dimiliki oleh seorang anak usia dini terdiri dari gerak lokomotor, non-lokomotor serta gerak manipulatif. Namun demikian pada 
artikel ini yang akan dibahas adalah mengenai gerak lokomotor. Kondisi yang ada di lapangan masih banyak anak yang gerak dasarnya salah. Gerak dasar yang dimaksud adalah gerak dasar yang paling sederhana yaitu berjalan, berlari dan melompat. Banyak anak yang melakukan jalan dengan ujung kaki yang mengarah ke luar, ke dalam, menapak dengan menggunakan bola kaki dll. Hal ini merupakan kesalahan umum yang ada. Oleh karena itu bagaimana guru harus mengajarkan teknik berjalan, berlari dan melompat akan dibahas pada artikel ini.

Pelaksanaan pembelajaran gerak dalam upaya membantu mengatasi kesalahan dalam gerak dasar, melalui aktivitas gerak yang dikaitkan dengan permainan. Dalam hidupnya manusia tidak akan terlepas dari aktivitas bermain. Bermain merupakan hal yang paling penting dalam kehidupan manusia. Bermain dimulai dari semenjak manusia dilahirkan. Bermain dalam kehidupan menjadi ciri bagi seorang individu. Antara 3 - 20\% waktu dan energy anak-anak dihabiskan untuk bermain (Pellegrini AD, Smith PK, 1998). Namun demikian tentunya perlu bagi orang tua dan guru untuk dapat mengarahakan anak-anak dalam melakukan permainannya sehingga tidak menimbulkan kesalahan gerak dasar dalam aktivitas yang dilakukannya.

\section{PEMBAHASAN}

PAUD adalah pendidikan yang harus dimulai dari keluarga. Namun demikian PAUD juga dilakukan di jenjang pendidikan formal maupun informal. PAUD dilakukan melalui kelompok bermain (KOBER), Taman Kanak-Kanak (TK), dll. PAUD dalam jalur formal harus mengembakan kemampuan anak yang mengacu kepada Permendikbud No 146 Tahun 2014 tentang Kurikulum PAUD Pasal 5 ayat 1 bahwa: "Struktur kurikulum PAUD memuat program-program pengembangan yang mencakup: a. nilai agama dan moral; b. fisik-motorik; c. kognitif; d. bahasa; e. sosial-emosional; dan f. seni." Oleh karena itu dalam konteks bermain bagi anak usia dini akan mengembangkan seluruh aspek secara menyeluruh.

Secara khusus dalam pengembangan fisik motorik seringkali terjadi anak tidak melakukan gerakan dasar dengan baik. Sehingga mengakibatkan gerak dasar yang harus dilakukan oleh anak tidak seuai dengan pergerakan yang seharusnya dilakukan. Padahal pergerakan yang baik akan membantu anak dalam melakukan aktivitasnya, terutama aktivitas bermain. Pergerakan yang terjadi dalam aktivitas bermain akan melibatkan organ tubuh baik dari sisi anatomisnya maupun sisi fisiologisnya. Pengalaman aktivitas gerak yang banyak meningkatkan 
kesehatan, kebugaran jasmani, dan komponen prilaku aktivitas fisik (Sholatuh $\mathrm{H}$, Myrnawati $\mathrm{CH}$, dan Moch Asmawi, 2017). Oleh karena itu melalui aktivitas bermain akan meningkatkan proses pertumbuhan dan peningkatan fungsi organ tubuhnya. Keterampilan gerak dasar dalam aktivitas bermain terdiri dari keterampilan gerak lokomotor, keterampilan gerak non lokomotor dan keterampilan gerak manipulatif. Menurut (Pangrazi \& Dauer, 1992)

1. Keterampilan gerak lokomotor dipergunakan untuk menggerakan tubuh dari satu tempat ke tempat lain termasuk mengangkat badan ke atas (melompat)

2. Keterampilan gerak non-lokomotor adalah gerakan tanpa adanya perpindahan tempat (menekuk, mendorong, menarik dll)

3. Keterampilan Manipulatif terjadi saat melakukan permainan ketika memainkan suatu objek menggunakan tangan, kaki serta bagian tubuh lainnya.

Keterampilan gerak dasar dalam bentuk ketiga keterampilan gerak harus dilatihkan dengan baik untuk mencapai kesempurnaan gerak di kemudian hari.

\section{Keterampilan Gerak Lokomotor}

Keterampilan gerak lokomotor terdiri dari berjalan, berlari, melompat, dll. Smith \& Pellegrini (2013) menyatakan bahwa permainan lokomotor terdiri dari bermain (lari, mendaki) yang melibatkan aktivitas tubuh yang didukung oleh otot, kekuatan, daya tahan dan keterampilan. Keterampilan gerak ini akan terus menerus menjadi bagian dalam kehidupan seharihari di masa yang akan datang. Oleh karena itu peran guru PAUD dalam memberikan pengajaran mengenai pergerakan lokomotor menjadi penentu keberhasilan aanak dalam menguasai gerak dasar pada keterampilan gerak lokomotor. Byers JA \& Walker C (1995) mengungkapkan bahwa latihan bermain meningkat dari anak-anak ke masa anak menjelang sekolah dan puncaknya pada usia Sekolah Dasar, ketika syaraf dan otot sebagai dasar koordinasi dan pertumbuhan kesehatan menjadi penting. Suatu permainan yang disetting oleh anak dan didukung oleh guru adalah bagian penting program pengembangan anak (Copple \& Bredekamp, 2009). Seringkali terjadi anak melakukan gerakan yang salah dan dibiarkan oleh guru atau orang tuanya sehingga menjadi kebiasaan yang salah. Ivrendi \& Isikoglu Erdogan (2015) menyatakan bahwa riset terbatas mengindikasikan bahwa guru kurang efisien dalam mencontohkan sutau permainan peluang bagi anak untuk bermain sangat besar. Setelah anak terbiasa dengan gerakan yang salah maka akan sulit untuk orang tua atau guru untuk 
mengkoreksinya. Oleh karena itu maka cara jalan yang benar harus diajarkan oleh guru maupun oleh orang tua kepada anak untuk mendapatkan keterampilan gerak dasar benar. Untuk beberapa keterampilan gerak lokomotor hal yang harus diperhatikan adalah sebagai berikut:

\section{Berjalan}

Berjalan adalah gerakan alamiah yang dilakukan oleh setiap individu. Berjalan yang dilakukan oleh orang dewasa dipelajari semenjak anak-anak. Seringkali guru menganggap bahwa anak dapat berjalan dengan benar secara alamiah padahal ketika orang tua atau guru tidak memberikan pelajaran yang benar untuk melakukan jalan yang baik maka kesalahan yang dilakukan oleh anak akan terbawa sampai usia dewasa dan menjadi prilaku yang menetap pada anak tersebut. Oleh karena itu bagaimana supaya orang bisa berjalan dengan baik maka harus diperhatikan rambu-rambu bagi para orang tua atau guru untuk mengajarkan anak-anak berjalan dengan baik. Pangrazi \& Dauer, (1992) mengungkapkan bahwa berjalan yang baik harus memperhatikan hal-hal sebagai berikut:

a. Kepala tegak dan pandangan lurus ke depan

b. Ujung jari kaki mengarah ke depan

c. Ayunan lengan dengan rilek

d. Berjalan tanpa suara e. Dada tegak

f. Melangkah dengan menekan menggunakan ujung jari kaki.

Kondisi ini bila dilakukan dengan baik maka akan menjadikan kebiasaan anakanak untuk melakukan jalan dengan baik. Kegiatan untuk mempelajari cara berjalan yang baik dapat dilakukan dengan berbagai macam cara, antara lain adalah :

1) Berjalan dengan melihat pada suatu objek/gambar yang ditempal di papan tulis.

Berjalan yang dilakukan dengan cara seperti ini akan membantu para siswa untuk meningkatkan kemampuan berjalan dengan badan tegak. Tegaknya badan membantu pergerakan tungkai menjadi lebih leluasa dalam arti bahwa tungkai dapat bergerak dengan membentuk sudut yang ideal untuk melangkah. Dengan posisi badan yang tegak akan mudah anak untuk mengkondisikan langkah yang panjang.

2) Berjalan pada satu garis lurus.

Anak diberikan pelajaran untuk berjalan pada satu garis lurus memungkinkan anak untuk dapat mengarahkan ujung jari kakinya mengarah ke depan. Kondisi seperti ini membantu anak untuk meningkatkan efisiensi jumlah langkah yang dilakukan dalam 
menempuh suatu jarak tertentu. Apabila ada deklinasi atau penyimpangan sudut yang dilakukan saat berjalan, misalkan ruas jari kaki mengarah ke luar atau ke dalam, maka akan terjadi pemendekan jarak yang telah ditempuh oleh seorang anak. Misal anak menempuh jarak 100 meter dengan tiga langkah/meter, artinya anak akan menempuh satu langkah 33,3 cm/langkah, artinya anak akan melangkah sebanyak 300 langkah dalam 100 meter. Selisih dua $\mathrm{cm}$ dari deklinasi maka anak dengan jalan yang salah akan ketinggalan jarak sejauh $300 \times 2 \mathrm{Cm}=6$ meter. Artinya anak tersebut akan menambah jumlah langkahnya sebanya 6 meter X 3 langkah $=18$ langkah.

Ini merupakan salah satu ilustrasi ketika kesalahan terjadi dalam pola langkah dengan ujung jari mengarah ke luar atau ke dalam. Dengan kesalahan yang dilakukan akan akan terjadi inefisiensi dalam jumlah langkah dan mengakibatkan jumlah kalori yang dibakarpun menjadi lebih besar. Oleh karena itu peran guru dan orang tua dalam melaksanakan pengajaran yang baik dalam hal gerak dasar pada anak menjadi kata kunci keberhasilan penguasaan gerak dasar yang baik.

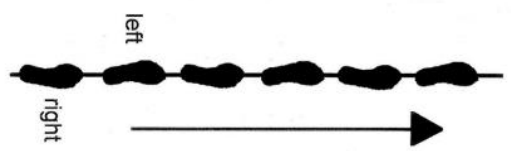

Gambar 1. Berjalan pada satu garis lurus

Sumber (IAAF (CECS), 2000)

3) Berjalan menggunakan ujung kaki

Pembelajaran berjalan dengan menggunakan ujung kaki dimaksudkan untuk membantu proses penolakan menjadi lebih cepat dan lebih efisien dibandingkan dengan dengan menggunakan seluruh tapak kaki saat menolak atau melangkah. Hal ini sesuai dengan prinsip keseimbangan dalam mekanika gerak manusia bahwa semakin kecil bidang tumpuan semakin labil benda tersebut ketika anak menggunakan ujung kaki maka tumpuan pada kkai menjadi lebih kecil sehingga lebih mudah untuk bergerak. Selain itu prinsip mekanika gerak yang kedua ketika menolak untuk melangkah dengan menggunakan ujung kaki adalah semakin tinggi jarak vertikal maka semakin labil benda tersebut. Pada saat menggunakan ujung kaki saat menolak maka posisi kaki akan jinjit sehingga posisi badan menjadi lebih 
tinggi/jarak vertical lebih tinggi sehingga memudahkan orang untuk dapat bergerak dengan lebih cepat.

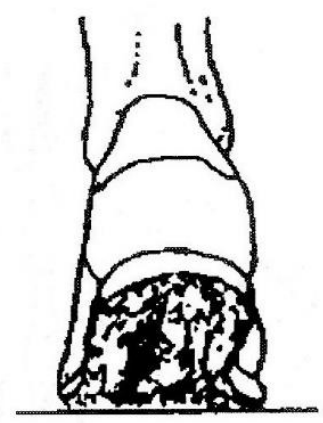

Gambar 2. Berjalan menggunakan ujung kaki

Sumber (IAAF (CECS), 2000)

4) Mendarat pada tumit saat melangkah.

Pendaratan yang baik untuk mendapatkan efisiensi energi yang dikeluarkan adalah dengan pendaratan saat melangkah menggunakan tumit. Secara umum pendaratan tersebut adalah pendaratan terbaik untuk mendapatkan cara berjalan yang baik. Pendaratan saat berjalan menggunakan ujung kaki dapat mengakibatakan inefisiensi dari berjalan hal ini dikarenakan pendaratan menggunakan ujung kaki rentang terhadap kelelahan karena kontraksi otot betis menjadi lebih besar ketimbang mendarat dengan menggunakan tumit.

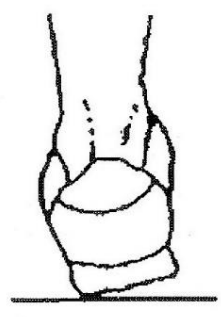

Gambar 3. Mendarat pada tumit saat melangkah

Sumber (IAAF (CECS), 2000)

5) Berjalan dengan ujung jari kaki mengarah ke dalam, atau mengarah keluar

Pembelajaran ini diberikan dalam upaya untuk mendapatkan perbandingan antara cara berjalan yang benar yaitu ujung jari kaki mengarah ke depan dengan ujung jari kaki mengarah ke dalam atau keluar mana yang lebih menguntungkan dari sisi jarak tempuh dan juga dari sisi efisiensi gerak otot.

\section{Berlari}

Berlari adalah gerak dasar manusia yang prinsip dalam kehidupan seharihari karena banyak aktivitas permainan yang harus dilakukan oleh anak dengan berlari. Namun demikian sikap lari yang baik harus dipelajari oleh anak dengan baik. Tentunya peran guru dalam memberikan pengarahan atau pelajaran tentang lari dilakukan sebaik mungkin karena menyangkut kemampuan anak di masa yang akan datang terutama dalam aktivitas kehidupan di masyarakat. Lari dan jalan sagatlah berbeda, perbedaan 
yang paling pokok adalaah kontak kaki dengan tanah. Pada berjalan selalau ada kontak salah satu kaki atau kedua kaki dengan tanah, sedangkan pada lari ada saat kedua kaki tidak menapak pada tanah. Pangrazi \& Dauer, (1992) mengungkapkan bahwa berlari yang baik dan benar dengan memperhatikan beberapa hal sebagai berikut:
a. Berlari menggunakan bola kaki
b. Kepala tegak dan pandangan ke depan
c. Tekukan lutut
d. Tubuh bagian atas rilek
e. Bernafas dengan alamiah
f. Ayunan lengan ke depan bukan ke samping

Faktor-faktor tersebut di atas menjadi kunci dari keberhasilan seorang peserta didik untuk melakukan lari dengan sebaikbaiknya. Untuk mendapatkan teknik berlari yang baik maka perlu dilatihkan bentukbentuk pembelajaran lari antara lain adalah:

1) Berlari langkah pendek

Gerakan yang sederhana dari pergerakan ini ditujukan untuk meningkatkan kemampuan untuk meluruskan lutut pada saat melakukan tolakan saat berlari. Selain itu juga gerakan ini membantu anak untuk merasakan saat melakukan tolakan dengan menggunakan ujung kaki. Selain itu dalam upaya meningkatkan ayunan lengan yang baik maka gerakan lengan diarahkan untuk dilakukan dengan rilek serta ayunan yag dilakukan diarahkan ke arah depan bukan mengarah ke samping. Seringkali ayunan lengan dilakukan dengan mengangkat kedua pundak ke arah atas sehingga membuat ketegangan pada bagian badan atas.

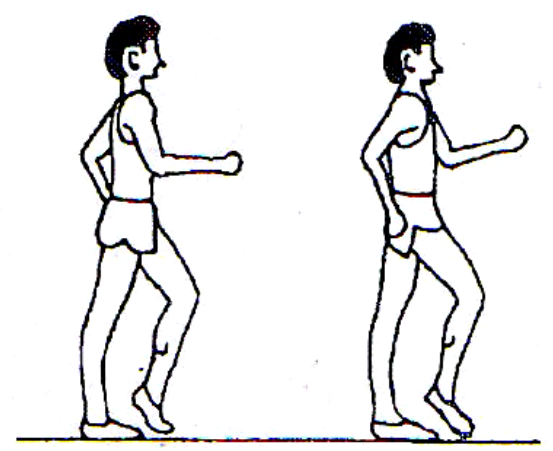

Gambar 4. Berlari langkah pendek (Sumber: IAAF (CECS), 2000)

2) Berlari dengan tumit menyentuh pantat

Berlari mengharuskan ayunan tungkai ke belakang dilakukan secara maksimal tidak diseret tetapi dilakukan dengan mengangkat tungkai bagian bawah. Tujuan dari gerakan tumit dikenakan ke pantat adalah untuk membiasakan anak didik untuk melakukan gerakan ayunan tungkai ke belakang dengan benar. Selain itu juga saat mengayunkan tungkai ke depan pendaratan dilakukan menggunakan bagian bola kaki yang ditujukan untuk 
mempersiapkan anak saat berlari harus menggunakan bola kaki untuk melakukan tolakannya. Serta mengajarkan anak untuk tetap focus dengan ayunan lengan yang harus dilakukan dengan rilek dan ayunan dilakukan ke depan.

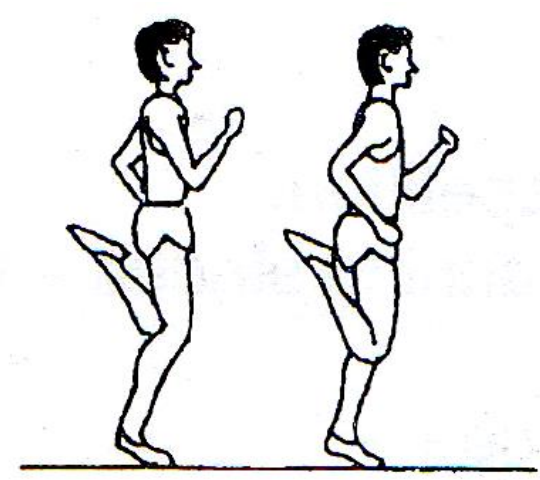

Gambar 5. Lari Tumit Menyentuh Pantat (Sumber: IAAF (CECS), 2000)

3) Berlari dengan mengangkat paha

Berlari mengangkat paha memungkinkan anak dapat melakukan lari dengan langkah yang panjang sehingga berlari bisa lebih efisien. Jarak tempuh yang jauh dapat ditempuh dengan langkah yang lebih sedikit sehingga tenaga yang dikeluarkan menjadi lebih sedikit. Pengangkatan paha juga membantu tolakan menjadi lebih kuat sehingga dorongan badan ke depan menjadi lebih cepat. Oleh karena itu bentuk pembelajaran gerak lari seperti ini membantu meningkatkan kemampuan anak dalam melakukan lari dengan baik dan benar.

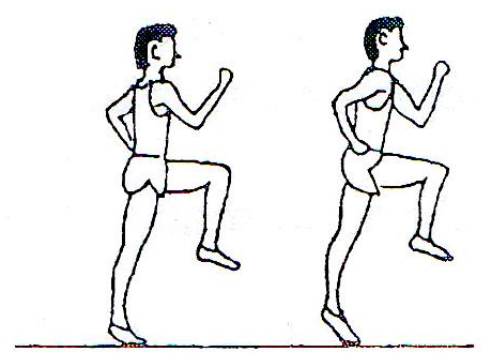

Gambar 6. Berlari Angkat Paha

(Sumber: IAAF (CECS), 2000)

4) Berlari dengan langkah yang bervariasi

Berlari dengan langkah yang bervariasi, yaitu langkah yang pendek maupun langkah yang panjang serta langkah yang standar. Pembelajaran lari dengan menggunakan langkah yang bervariasi memberikan kesempatan kepada anak untuk memberikan pengalaman gerak kepada peserta didik. Pengalaman gerak yang dimaksud adalah bagaimana dia merasakan ketika harus melakukan gerakan berlari dengan langkah panjang, dengan langkah pendek maupun dengan langkah standar.

5) Berlari dengan mengikuti bentuk tertentu (lingkaran, segitiga, angka 8, dll) 
Formasi atau bentuk lintasan yang diciptakan oleh guru merupakan suatu hal yang membantu para peserta didik untuk mengalami berbagai kondisi ketika lintasan yang harus ditempuh anak bervariasi. Lintasan melingkar, lintasan yang lurus memberikan pengalaman kepada anak untuk dapat melakukan gerak lari dengan berbagai kondisi. Pengalaman berlari seperti ini memberikan peluang kepada peserta didik untuk dapat melakukan gerakan berlari pada berbagai kondisi baik saat harus berlari berkelok maupun berlari pada lintasan yang lurus.

\section{Melompat}

Bentuk gerakan lokomotor yang lain adalah gerakan melompat. Gerakan melompat adalah gerakan lokomotor yang mesti dimiliki oleh seorang peserta didik untuk kebutuhan dirinya dalam berbagai aktivitas di kemudian hari. Melompat bagi anak usia dini harus memperhatikan hal yang paling pokok yaitu janganlah anak terlalu banyak diberikan gerakan melompat ke atas. Hal ini dikarenakan anak usia dini sedang mengalami masa pertumbuhan, dikhawatirkan anak dengan loncatan yang tinggi apabila proses pendaratan tidak dilakukan dengan benar akan mengakibatkan cedera pada anak usia dini. Oleh karena itu maka perlu diperhatikan oleh guru untuk mengarahkan anak usia dini pada saat melakukan lompatan. Hal ini ditujukan untuk membantu mengurangi resiko anak usia dini mengalami cedera. Pangrazi \& Dauer, mengungkapkan bahwa hal yang harus diperhatikan oleh guru saat memberikan pembelajaran lompat adalah sebagai berikut:

a. Ayun lengan ke depan secepat mungkin

b. Lutut ditekuk

c. Melompat menggunakan ujung kaki

d. Mendarat dengan lembut dengan posisi lutut ditekuk

e. Melompat ke atas/ke depan Beberapa bentuk materi pelajaran lompat dapat diberikan kepada anak usia dini. Hal ini dimaksudkan untuk meningkatkan keterampilan gerak lokomotor. Melompat adalah aktivitas gerak dasar bagi anak untuk menyiapkan diri dalam kehidupannya di masa yang akan datang. Namun demikian perlu diperhatikan bahwa gerakan yang dilakukan harus mengikuti aturan dalam upaya menghindari terjadinya cedera saat melakukan gerakan tersebut. Bentuk pembelajaran lompat yang bisa 
diberikan kepada peserta didik

antara lain adalah:

1) Melompat ke atas

Gerakan melompat dapat dilakukan ke berbagai arah baik ke atas, depan, belakang, maupun ke samping. Gerakan melompat yang umum dilakukan salah satunya adalah gerakan melompat ke atas. Gerakan melompat ke atas merupakan pergerakan yang banyak dibutuhkan dalam aktivitas kehidupan sehari-hari. Oleh karena itu sangatlah perlu bagi guru untuk memberikan pembelajaran gerak melompat ke atas bagi peserta didik. Namun perlu diperhatikan pengulangan gerak lompat ke atas jangan diberikan terlalu banyak.

Hal ini dimaksudkan untuk menghindari kemungkinan cedera yang dapat diakibatkan oleh karena kesalahan pendaratan yang dilakukan oleh anak.

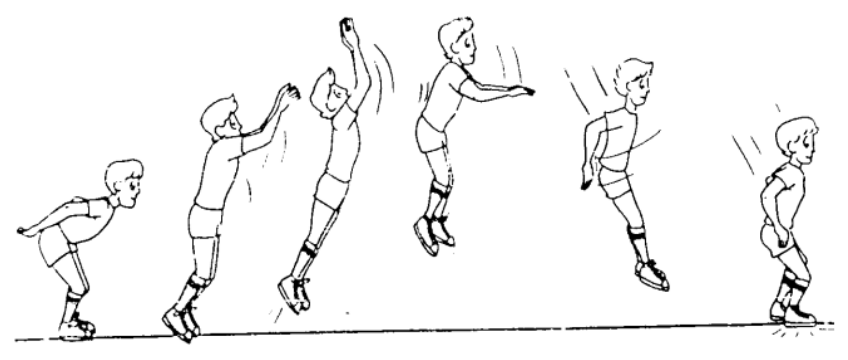

Gambar 7. Melompat ke atas

Sumber (Boompa, 2000)
2) Melompat ke depan

Gerakan melompat yang lain yang dilakukan adalah gerakan melompat ke arah depan. Gerakan ini dalam aktivitas sehari-hari juga sangat sering dilakukan terutama untuk menghindari suatu benda atau parit dll. Oleh karena itu lompat ke depan juga harus diberikan kepada peserta didik dalam upaya meningkatkan keterampilan gerak lokomotor.

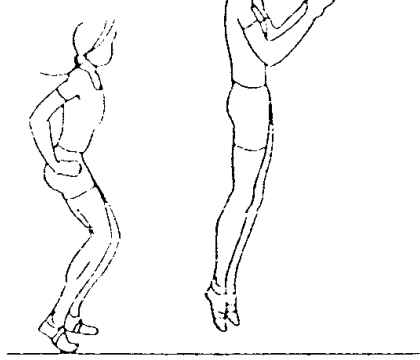

Gambar 8. Melompat ke depan (Sumber: Rushall \& Pyke, 1993)

3) Melompat ke samping

Lompatan ke samping juga harus diajarkan kepada anak usia dini dalam upaya memberikan pengalaman gerak kepada anak, untuk bekal di kehidupan yang akan datang. Dengan demikian maka anak akan terbiasa dengan bentuk gerakan yang bervariasi yang mungkin muncul dalam aktivitas hidup. Gerakan ini bisa 
diberikan dengan bentuk ke samping kiri atau kanan serta juga bisa diberikan rintangan dalam bentuk garis, atau benda lain yang tidak membahayakan bagi anak. Selain itu juga bisa diberikan dalam bentuk lompatan ke samping dengan pola zig-zag.

4) Melompat sambil berputar

Melompat sambil berputar sangatlah sulit namun demikian bisa dilakukan dengan berbagai variasi dimulai dari gerakan yang mudah. Misalnya gerakan melompat sambil berputar $45^{\circ}, 90^{\circ}$, sampai pada gerakan melompat sambil berputar $180^{\circ}$. Dengan demikian anak diberikan peran untuk tumbuh dan berkembang dalam keterampilan gerak, sesuai dengan perkembangan tingkat usianya.

5) Melompat menirukan gerakan binatang

Anak sangat senang serta mengingat hal-hal yang ada di lingkungan sekitarnya. Selain itu juga anak selalu meniru gerakan gerakan yang muncul dari lingkungan sekitarnya atau dari apa yang dilihatnya. Oleh karena itu maka sambil mengenalkan jenisjenis binatang maka sebaiknya guru juga mengajarkan tentang gerakan yang dilakukan oleh binatang baik cara berjalannya, berlari maupun cara melompat dengan demikian akan tidak merasakan kejenuhan saat melakukan materi pelajaran yang diberikan. Smith PK, Dalgeish M, \& Herzmark G. (1981) menyatakan bahwa, latihan bermain dapat menyenangkan dan cara efektif untuk memperbaiki pengembangan bahasa, kognitif kreativitas dan pengambilan peran.

Dalam pelaksanaanya gerak lokomotor lebih cenderung untuk melibatkan otot-otot besar seperti yang diungkapkan oleh Meanwhile, sigelman dan Rider (2012) bahwa : keterampilan motorik kasar adalah keterampilan seperti menendangkan tungkai, menggambar lingkaran besar yang melibatkan otot besar dan seluruh bagian tubuh atau anggota gerak.

Keterampilan gerak dasar harus dilatihkan. Sebelum masuk sekolah anak harus mendapatkan aktivitas gerak atau mengacu kepada keterampilan gerak dasar (Morano, Colella dan Caroli, 2011). Tanpa proses pelatihan tidaklah mungkin anak akan mencapai tingkat perkembangan motorik yang sesuai dengan tingkat perkembangan usianya. Karena dengan pengalaman melakukan aktivitas gerak menjadi dasar untuk meningkatkan keterampilan yang lebih komplek di kemudian hari (Sholatuh $\mathrm{H}$, Myrnawati 
CH, Moch Asmawi, 2017). Keterampilan gerak dasar motorik kasar terdiri dari berjalan, berlari, merangkak, Seringkali anak mengalami keterlambatan dalam menguasai keterampilan motorik halus, antara lain koordinasi mata dan tangan yang belum terarah, kekuatan, kecepatan, kelincahan dan kelenturan anak belum terlihat secara jelas. Oleh karena itu perlu untuk memberikan pengalaman gerak bagi anak melalui pembelajaran yang terarah untuk memperbaiki kesalahan gerak yang dilakukan oleh anak.

\section{KESIMPULAN}

Anak merupakan individu yang harus dilatih untuk memiliki gerak dasar yang baik dan benar. Melalui pembelajaran yang baik yang dilakukan oleh orang tua dan guru, diharapkan kebiasaan yang salah dari gerak dasar dapat diminimalisir. Pada dasarnya manusia adalah mahluk yang senang bermain. Bagi anak-anak, teori surplus energi adalah salah satu teori yang mengungkapakan bahwa anak-anak memiliki kelebihan energi sehingga kelebihan tersebut harus disalurkan melalui aktivitas bermain baik bermain sendiri maupun bermain dengan interaksi dengan teman-temannya. Dengan aktivitas permainan mereka menemukan gerak dasar terutama gerak lokomotor antara lain berupa berjalan, berlari dan melompat. Namun demikian seringkali terjadi kesalahan gerak yang dilakukan oleh mereka ketika melakukan permainan.

Oleh karena itu peran dari para orang tua dan guru untuk memperbaiki teknik gerak dasar yang dilakukan oleh anak-anak sangatlah penting dengan memberikan bentuk-bentuk permainan atau bentuk pembelajaran yang mengarahkan kepada pembetukan gerak dasar yang baik dan benar. Rambu-rambu teknik gerak dasar seringkali tidak diketahui oleh para orang tua dan guru sehingga tidak pernah mereka memperhatikan benar atau salah dari gerak dasar yang dilakukan oleh anak-anaknya. Oleh karena itu maka peting kiranya guru untuk mengetahui bagaimana seharusnya mereka memberikan pengajaran tentang teknik gerak dasar. Selain itu juga mereka harus mengetahui bagaimana teknik dasar tersebut harus dilakukan.

Dalam pelaksanaan permainan yang dilakukan anak-anak peluang yang besar bagi anak-anak untuk mengembangkan dirinya dengan bermain bebas, juga keterlibatan orang tua atau guru dalam permainan sebagai tutor (Smith \& Pellegrini, 2013). Dalam pengembangan gerak dasar bagi anak-anak yang paling penting adalah berikan kebebasan untuk bergerak namun mesti diperhatikan teknik dasar dari gerakan yang akan diajarkan kepada mereka. 
DAFTAR PUSTAKA

Boompa, Tudor O. 2000, Total Training for Young Champion. New York: Human Kinetic.

Byers JA \& Walker C (1995). The refining motor training hypothesis for the evolution of play. Aamerican Naturalist. 146 (1) (pp. 25-40)

Copple C, \& Bredekamp, S, (2009). Developmentally Appropriate practice in early childhood programs: Serving children from birth through age 8. Washington, DC: NAEYC.

IAAF (CECS), 2000, Run, Jump, Throw. Jerman: IAAF

Ivrendi, A., \& Isikoglu Erdogan, N. (2015). Play in a Turkish cultural context. In J. Roopnarine, M.M. Patte, E Johnson, \& D Kuscher (Eds), International Perspectives on childrens play (pp. 210-221. New York : Open University Press.

Morano, Colella dan Caroli, (2011). Gross Motor Skill Performance in a Sample of Overweight and NonOverweight Preschool Children. International Journal of Pediatric Obesity, 2011; Vol. 6 (S2). P 42.

Permendikbud No 146 Tahun 2014 tentang Kurikulum PAUD

Pangrazi \& Dauer, 1992). Dynamic Physical Education for Elementary School Children. New York: Macmillan

Rushall \& Pyke (1993). Physiology of Sport. London: Human Kinetik

Sholatuh H, Myrnawati CH, Moch Asmawi, (2017), Effect of
Traditional Games, Learning Motivation and Learning Style on Childhoods Gross Motor Skill. InternTIONAL Journal of Education and Research. Vol 5 No 7 July 2017. P. 53-66.

Sigelman dan Rider (2012), Life-Span Human Decvelopment. Belmont: Wadsworth

Smith PK, Dalgeish M, \& Herzmark G. (1981). A comparison of the effects of fantasy play tutoring and skill tutoring in nursery classes. International Journal of Behavioral Development: 4 (4) (pp. 421-441)

Smith, Peter, K., \& Pellegrini, A. (2013). Learning Through Play. Encyclopedia on early Chilhood Development. (pp. 1-5). 